\title{
Incidence and severity of major diseases of coffee in highland of eastern Ethiopia
}

\author{
Abdi Adem ${ }^{1 *}$ and Mohammedsani Amin ${ }^{2}$ \\ ${ }^{1}$ Department of Horticulture, Dilla University, P.O.Box 419, Dilla, Ethiopia, ${ }^{2}$ Mechara Agricultural Research Centre, P.O.Box: 19, West Harerghe, \\ Mechara, Ethiopia
}

(Received: August 29, 2020; Revised: July 11, 2021; Accepted: July 12, 2021; Published:August 06, 2021)

*Corresponding Author: Abdi Adem(E-mail: abdi.ademame@gmail.com)

\begin{abstract}
This study was conducted with the objective to assess the incidence and severity of coffee berry disease (CBD) and coffee leaf rust (CLR) in the highland of Eastern Ethiopia. In the east Hararge Zone of Eastern Ethiopia, coffee was grown by 331,651 holders on 7,584 ha with a production output of 3,722 tons and a yield of 0.5 ton/ha in 2017. Bedeno is the leading coffee producer district in the Zone followed by Melka-ballo, Deder and Meta districts. In Bedeno, coffee is mainly grown in altitudes ranging from 1690 to 2260 masl. Coffeeberry disease and leaf rust are the two major diseases of coffee in the area. A total of 34 representative coffee farms at nine study sites (3-4 coffee farms at the interval of 3-5 kilometers) were selected through discussion with Bedeno district's coffee experts. The study sites were selected using sequential sampling techniques through discussions with district's coffee experts. Incidence of coffee berry disease and leaf rust was determined as percentage of diseased trees. Disease severity was determined as percentage of diseased coffee berries per plot. Data were analyzed using descriptive statistics. The result of this study revealed the incidence of CBD in Bedeno district ranged from 30.0 to $93.3 \%$ with a mean of $70.19 \%$. The severity of the CBD was from $13.3 \%$ to $44.4 \%$ with an average severity of $28.53 \%$. Both incidence and severity of CBD were high at Barkalle followed by Barakat and Hindhessa areas. On the other hand, the incidence of coffee leaf rust varied from 18.9 to $87.4 \%$ with mean of $52.7 \%$. The high mean incidence of CLR at highland areas of eastern Ethiopia is clear evidence for occurrence of climate change in the area. Hence, it is advisable to introduce improved coffee varieties that are resistant to coffee berry disease and leaf rust for production in the area. Training farmers to implement proper cultural disease management practices such as prunning and sucker management will also help alleviate the constraint.
\end{abstract}

Key words: Coffee berry disease, coffee leaf rust, Eastern Ethiopia, Incidence, Severity

\section{INTRODUCTION}

Coffee is the principal cash crop in Ethiopia. The country is the $5^{\text {th }}$ and $1^{\text {st }}$ coffee producer in the world and Africa, respectively. Coffee is a means of livelihood for one-fourth of the country's population. Ethiopia earned 839 million dollar from coffee export in 2018. Coffee shared about 30\% of income from all commodities in same year (NBE, 2019). Ethiopia is the center of origin and diversity for Arabica coffee (Bayeta et al., 2007). The coffee types of Ethiopia that are distinguished for their very fine quality, unique aroma and flavor characteristics include Harer, Sidamo, Yirgacheffe, Ghimbi and Limu types (Workafes and Kassu, 2000).The contribution of Harer coffee to the total country's export is 8\% (Desse, 2018). Harer coffee is grown in East and West Hararge Zones, in Eastern Ethiopia.

In east Hararge Zone, coffee was grown by 331,651 holders on 7,584 ha with production output of 3,722 ton and yield of 0.5 ton/ha in 2017 (CSA, 2017). Bedeno is the leading coffee producer district in the Zone followed by Melka-ballo, Deder and Meta districts. In Bedeno, coffee is mainly grown in highland with altitude ranging from 1690 to 2260 masl. Coffee berry disease and leaf rust have been major constraints of coffee production in highland of eastern Ethiopia. Coffee berry disease was first reported in Kenya in 1922 (McDonald, 1926) and occurred in Ethiopia in 1971 (Hindorf, 1975). The national average severity of CBD is 24-30\% on local land races (Tefesetewold, 1995; Eshetu, 1997). But crop loss due to CBD may reach up to $100 \%$ in area with high rainfall and at higher altitude (Van der Graaff, 1981). CBD caused up to $100 \%$ yield loss in Hararge in 19070s (Tefestewold and Mengistu, 1989).

Coffee leaf rust was first reported in 1934 in Ethiopia (Sylvian, 1955). The disease is widely distributed all over coffee growing areas of the country with varying intensities. Average national infected coffee trees by the rust increased from $12.9 \%$ in 1980 to $36.3 \%$ in 1990 (Chala et al., 2010; Girma et al., 2016). The result of study conducted three decades ago revealed that severity of the coffee leaf rust was high (27\%) in Hararge area (Eshetu, 2000). In studies conducted before three decades, both CBD and leaf rust were major constraints of coffee production in Hararge area. There was a need to know current status of the two diseases in the area.

\section{Objectives}

Accordingly, this study was conducted with the objective to assess incidence and severity of coffee berry disease (CBD) and coffee leaf rust (CLR) in highland areas of eastern Ethiopia. 


\section{MATERIAL AND METHODS}

\section{Study area}

This study was conducted in August 2014 in Bedeno district, Eastern Ethiopia. Bedeno district is bordered on the south by Gola Oda, on the east by Girawa, the northeast by Kurfa-chelle, on the north by Jarso, on the northwest by Meta, on the west by Deder and on the southwest by Malkaballo. The altitude of the district ranged from 1200 to 3100 meters above sea level. Aniya Geneme is the highest point. However, the altitude of study sites ranged from 1690 to 2260 masl. Coffee is mostly grown within this range of the altitudes.

\section{Sampling}

Incidence and severity of coffee berry disease assessment under field condition was conducted following procedures used by (Arega et al., 2008). Coffee leaf rust incidence was determined as procedures used by (Eskes and Toma-Braghini, 1981). Through discussion with district's coffee experts, representative coffee grower areas were identified based on coffee production potential and representativeness. Then, 3-4 coffee farms were selected as sample plots at the interval of 3-5 kilometers. Accordingly, 34 coffee farms were selected from nine coffee producer areas. The selected farms were assessed for coffee berry disease and coffee leaf rust.

\section{Data collection and analysis}

\section{Coffee berry disease}

For coffee berry disease, incidence (occurrence) and severity (intensity) were recorded. Incidence of CBD was studied by visual assessment. About 15-30 coffee trees per farm (depending on the number of coffee trees of studied plot) were randomly selected and diagnosed for presence and absence of the disease. Then, disease incidence was calculated as number of diseased trees divided by total observed trees and multiplies by 100 . On the other hand, disease severity was determined using berry counting method. Then, 10 coffee trees per plot (following diagonal and zigzag line) were randomly selected and each tree divided into three strata of branches (top, middle and bottom). From each stratum one branch was selected and the number of CBD infected and that of healthy berries was recorded. From that, percentage of diseased coffee berries was worked out.

\section{Coffee leaf rust (CLR)}

Assessment of coffee leaf rust incidence was conducted on 10- 15 randomly selected trees per coffee farm. Number of healthy trees and diseased trees were counted. Then, the incidence of CLR was calculated as percentage of diseased trees. In addition to disease assessments, coffee farms were observed through transect walk. Furthermore, the farmers were interviewed using structured questionnaires to collect information like about farming system, coffee cultivars, age of trees.

\section{RESULT AND DISCUSSION}

\section{Coffee farming system}

Age of coffee trees in the study area varied. Coffee trees in $75 \%$ of the sampled farms were less than 10 years. About $12.5 \%$ were from 11 to 20 years of age while the remaining $12.5 \%$ were between 21 and 30 years of age. In the area coffee was intercropped with one or more crops. Coffee was intercropped with maize in $25 \%$ of the studied farms, with maize and chat (25\%), with maize and fenugreek (12.5\%), with maize and linseed $(12.5 \%)$ as well as with barley and Chat $12.5 \%$. Only about $12.5 \%$ of the farms grew coffee alone. Farmers grew local cultivars namely Shunkuyi, Torbi and Charcharo. No improved variety was reported to grow in the area. Characharo is resistant to $\mathrm{CBD}$, while Shunkyi is moderately resistant to both CBD and CLR. Both landraces are high yielder but irregular in bearing according to respondent farmers.

\section{Incidence and severity of coffee berry disease (CBD)}

Incidence of CBD ranged from 30\% at Ilili Darartu Caffe to $93.3 \%$ at Barkalle with mean incidence of $70.19 \%$ (Table 1). Severity of the CBD varied from $13.3 \%$ at Tortora Kella Mumad to $44.4 \%$ at Barkalle with mean severity of $28.53 \%$. Both incidence and severity of CBD was high at Barkalle (Table1 and Figure1) followed by Barakat and Hindhessa. Both incidence and severity of CBD in highland areas of easten Ethiopia were higher than national average (25-30\%). This might be due to the low temperature in the high altitude and use of susceptible coffee cultivars in the area. The incidence of CBD in different parts of the country was assessed in different regions of Ethiopia at various times (Tefesetewold, 1995; Eshetu, 2000).

\section{Incidence of coffee leaf rust (CLR)}

Incidence of coffee leaf rust ranged from $18.9 \%$ at Ilili Darartu Adam to $87.4 \%$ at Ilili Darartu Caffe-04 with mean

Table 1: Incidence and severity of coffee berry disease and leaf rust in Bedeno district, highland of eastern Ethiopia

\begin{tabular}{|c|c|c|c|c|}
\hline \multirow[t]{2}{*}{$\mathrm{SN}$} & \multirow[t]{2}{*}{ Study site } & \multicolumn{2}{|c|}{$\begin{array}{c}\text { Coffee berry disease } \\
(\mathrm{CBD})\end{array}$} & \multirow{2}{*}{$\begin{array}{c}\text { Leaf rust } \\
\text { (CLR) } \\
\begin{array}{c}\text { Incidence } \\
(\%)\end{array}\end{array}$} \\
\hline & & $\begin{array}{c}\text { Incidence } \\
(\%)\end{array}$ & $\begin{array}{l}\text { Severity } \\
(\%)\end{array}$ & \\
\hline 1 & Barakat & 86.7 & 33.2 & 27.1 \\
\hline 2 & Barkalle & 93.3 & 44.4 & 21.7 \\
\hline 3 & Hindhessa & 92.0 & 32.8 & 23.0 \\
\hline 4 & Tortora kella Arrolle & 60.0 & 36.6 & 69.1 \\
\hline 5 & Tortora Kella Mumad & 55.0 & 13.3 & 79.4 \\
\hline 6 & $\begin{array}{l}\text { Tortora Kella } \\
\text { Abbadho }\end{array}$ & 66.7 & 28.9 & 81.6 \\
\hline 7 & Ilili Darartu Caffe-04 & 64.0 & 20.4 & 87.4 \\
\hline 8 & Ilili Darartu Caffe -01 & 30.0 & 22.5 & 65.8 \\
\hline \multirow[t]{3}{*}{9} & Ilili Darartu Adam & 84.0 & 24.6 & 18.9 \\
\hline & Mean & 70.2 & 28.5 & 52.7 \\
\hline & Average deviation & 16.7 & 7.4 & 26.7 \\
\hline
\end{tabular}




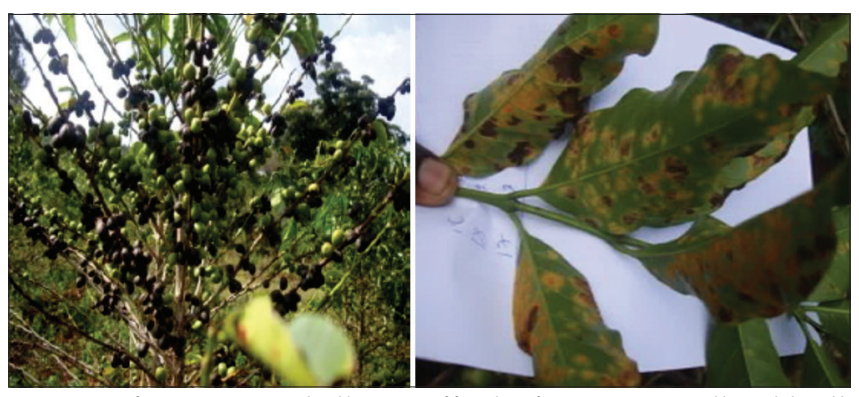

CBD infection at Barkalle Coffee leaf rust at T/ Kella Abbadh

Figure 1: Coffee infected by Coffee berry disease (left) and leaf rus (right) t observed at study sites.

of $52.7 \%$. Incidence of CLR was relatively low at Barkalle, Barakat and Hindhessa. The current result is in agreement with the findings of [8]. The high mean incidence of CLR at highland areas of eastern Ethiopia is a clear evidence for the occurrence of climate change in the area. It is advisable to introduce improved coffee varieties which are resistant coffee berry disease and leaf rust. Training farmers to implement proper cultural disease management practices such as pruning and sucker management will also help alleviate the constraint.

\section{CONCLUSION AND ECOMMENDATION}

The result of the present study revealed that incidence of CBD in Bedeno district ranged from 30.0 to $93.3 \%$ with mean value of $70.19 \%$. Severity of the disease varied from $13.3 \%$ to $44.4 \%$ at with average severity of $28.53 \%$. Both incidence and severity of CBD were high at Barkalle followed by Barakat and Hindhessa. On the other hand, incidence of coffee leaf rust was from 18.9 to $87.4 \%$ with mean of $52.7 \%$. The high mean incidence of CLR at highland areas of eastern Ethiopia is a clear evidence for climate change. It is advisable to introduce improved coffee varieties which are resistant coffee berry disease and leaf rust. Training farmers to implement proper cultural disease management practices such as pruning and sucker management will also help alleviate the constraint.

\section{ACKNOWLEDGEMENT}

The authors would like to thank Mulugeta Mamo, Yitagesu Kuma and Assefa Juhar for their help in data collection and Mechara Agricultural Research Center for financing the research project.

\section{REFERENCES}

Arega, Z., Demelash, T., Chala, J., Sisay, T., Mesfin, S., and Girma, A. (2008). Success Stories in Managing Coffee Berry Disease in Ethiopia. In A. Girma, B. Bayetta, S. Tesfaye, T. Endale and K. Taye. (Eds.), Coffee Diversity and Knowledge (pp. 239 - 249). Proceedings of a National Workshop Four Decades of Coffee
Research and Development in Ethiopia, 14 -17 August 2007, Addis Ababa, Ethiopia.

Bayeta, B., Labouisse, J. P., Hamelin, C., Kotecha, S., and Bertrand, B. (2007). Collection and ex-situ conservation of coffee landraces in Ethiopia: The example of harerge. In $21^{\text {st }}$ International Conference on Coffee Science, Montpellier (France), $11^{\text {th }}$ to $15^{\text {th }}$ September 2006. ASIC, pp. 926-930.

CSA. (2017). Central Statistical Agency of Ethiopia. Report on Area and Production of major crops in Ethiopia. Annual Agricultural Sample Survey of 2016/17, Statistical Bulletin 584. Volume I. Addis Ababa, Ethiopia. pp.50-53.

Desse N. (2008). Mapping Quality profiles of Ethiopian Coffee by Origin. In Proceeding of a National Workshop Four Decades of Coffee Research and Development in Ethiopia, 14-17 August 2007, Addis Ababa, Ethiopia. pp. 317-327.

Eshetu, D. (1997). Coffee diseases and their significance in Ethiopia. ASIC, 17(I), 723-726.

Eshetu, D. (2000). Control of coffee berry disease by fungicides in Ethiopia. In Proceedings of the workshop on control of coffee berrydisease (CBD) in Ethiopia. 13 - 15 August 1999, Addis Ababa, Ethiopia. pp. 35 - 46.

Eskes, A., and Toma-Braghini, M. (1981). Assessment methods for resistance to coffee leaf rust (Hemileia vastatrix Berk. Et Br.) Plant protection bulletin. FAO 29:56-66. Journal of Plant Diseases and Protection, 108 (2), 136-142.

Girma, A., Challa, J., and Hindrof, H. (2016). Interactions of Coffee Leaf Rust (Hemileia vastatrix) with Its Host Across Production Systems of Ethiopia. The proceeding of $26^{\text {th }}$ International Conference on Coffee Science, November 13-19, Kunming, China, pp. 382.

Hindorf, H. (1975). Colletotrichum occurring on Coffea arabica: A Review. Journal of Advanced Research,5(3), 43-56.

Chala, J., Chemeda, F., Girma, A., and Holger, H. (2010). Coffee Leaf Rust Epidemics (Hemileia vastatrix) in Montane Coffee (Coffea arabica L.) Forests in Southwestern Ethiopia. East African Journal of Sciences, 4, 86-95. https://doi.org/10.4314/eajsci.v4i2.71530

McDonald, J. (1926). A preliminary account of a disease of green coffee berries in Kenya colony. Transactions of the British Mycological Society, 11, 145-154. https://doi.org/10.1016/ S0007-1536(26)80033-6

NBE. (2019). National Bank of Ethiopia Annual Report of the year 2017/18, pp. 67-69.

Sylvian, P. G. (1955). Some observatios on Coffea Arabica L. in Ethiopia. Turrialba, 5, 37-53.

Tefesetewold, B. (1995). Studies of Colletotrichum population on Coffea arabica L. In Ethiopia and evaluations of the reactions of coffee germplasm. PhD Dissertation, University of Bonn, Germany. pp. 231.

Tefestewold, B., and Mengistu, H. (1989). Colletotrichum species associated with coffee berry disease in Hararghe. Ethiopian Journal of Agricultural Sciences, 11, 1- 6 .

Van der Graaff, N. A. (1981). Selection of Arabica coffee types resistance to coffee berry disease in Ethiopia. Mededelingen Landbouwhogeschool, Wageningen 81-11, 110.

Workafes, W., and Kassu, K. (2000). Coffee production system in Ethiopia. In Proceedings of the Workshop on Control of Coffee Berry Disease in Ethiopia, 13-15 ${ }^{\text {th }}$ August, 1999, Addis Ababa, Ethiopa. 